DOI: http://dx.doi.org/10.33846/hn50401

http://heanoti.com/index.php/hn

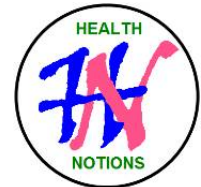

RESEARCH ARTICLE

URL of this article: http://heanoti.com/index.php/hn/article/view/hn50401

\title{
Profile of Patients with Ear, Nose, and Throat Foreign Bodies on Emergency Room,
} RSUD Dr. Soetomo in 2018

\author{
Raka Ihsanulhaj ${ }^{1}$, Rizka Fathoni Perdana ${ }^{2(\mathrm{CA})}$, Sahudi Abdul Mujib ${ }^{3}$, Puguh Setyo Nugroho ${ }^{4}$ \\ ${ }^{1}$ Faculty of Medicine, Universitas Airlangga, Indonesia; rakaihsan@ gmail.com \\ ${ }^{2(\mathrm{CA})}$ Department of Otorhinolaryngology Head and Neck Surgery, Faculty of Medicine, Universitas Airlangga, \\ Indonesia; rizka-f-p@ fk.unair.ac.id (Corresponding Author) \\ ${ }^{3}$ Department of Surgery, Faculty of Medicine, Universitas Airlangga, Indonesia; sahudisurg@yahoo.co.id \\ ${ }^{4}$ Department of Otorhinolaryngology Head and Neck Surgery, Faculty of Medicine, Universitas Airlangga, \\ Indonesia; puguh-s-n@fk.unair.ac.id
}

\begin{abstract}
Foreign bodies in the ear, nose, and throat (ENT) is a common emergency case found in the emergency room. On 2016, it was found that 689 patients admitted to RSUD Dr. Soetomo's emergency room due to foreign bodies on their ear, nose, or throat. This study aims to determine the profile of patients with foreign bodies on their ear, nose, or throat that admitted to Emergency Room, RSUD Dr. Soetomo in 2018. This type of research was a retrospective study using medical records of patients. The total of patients in this study was 802 patients. It was found that the most common foreign bodies was found on ear with 342 cases $(42.64 \%)$, followed by nose with 265 cases (33.04\%), and lastly throat with 195 cases $(24.31 \%)$. The most common patients age group was $0-10$ years with 376 cases $(46.88 \%)$, followed by patients with age group more than 50 years with 93 cases $(11.60 \%)$. There were more males patients with 445 patients $(55.49 \%)$ rather than women with 357 patients $(44.51 \%)$. The most common foreign bodies on ear was cotton with 173 cases $(50.58 \%)$. The most common foreign bodies on nose was bead with 137 cases $(51.70 \%)$. The most common foreign bodies on throat was fish bone with 166 cases $(85.13 \%)$. The standard procedure for patients with foreign bodies was with extraction, extra procedure may be needed according to the condition of patients. Most of the patients showed no complication after the treatment.
\end{abstract}

Keywords: foreign bodies; the ear, nose, and throat (ENT), profile of patients

\section{INTRODUCTION}

\section{Background}

Foreign bodies on ear, nose, and throat is a common cases on the emergency room. On 2016, it was found that 689 patients admitted to Emergency Room, RSUD Dr. Soetomo due to foreign bodies on their ear, nose, or throat. Big number of patients with this problem was indicating that update of data was necessary to really gave us the picture of how big of a problem foreign bodies on ear, nose, and throat were. On 2016, it was found that the most common place for foreign bodies is on the ear $(53,6 \%)$, followed by nose $(34.4 \%)$, and lastly throat $(12 \%)^{(1)}$. Currently there were no epidemiological data on patients with foreign bodies in ear, nose, and throat on 2018 in RSUD Dr. Soetomo. Update of current data was necessary to see how big of a problem is foreign bodies to emergency cases that year. Update of current data also could be the base of more comprehensive research regarding this topic about foreign bodies.

\section{Purpose}

The purpose of this study was to find profile of patients with foreign bodies on their ear, nose, or throat that was admitted to Emergency Room, RSUD Dr. Soetomo in 2018. This data could be the base for next study regarding this topic of foreign bodies on ear, nose, or throat. 


\section{METHODS}

This research was using observational descriptive method. The data was collected through medical records on logbook for Departement of Otorhinolaryngology Head and Neck Surgery's emergency room. Data collected for patients that admitted on period of January-December 2018. The sample was patients with foreign bodies on their ear, nose, or throat that was admitted to Emergency Room, RSUD Dr. Soetomo in 2018. Total population sampling was used as our method to fully captured the phenomena of foreign bodies on that year. Variables were site of foreign bodies, age group of patients, their sex identification, type of foreign bodies on each anatomical site, therapy that was done, and complication occurred after the treatment was done. Data of each variable were collected through the medical records. There were no exclusion of data since all of the necessary variable was available on medical records. Data that collected then being processed with computer software then shown descriptively. This research was already approved ethically by the Reasearch and Development Department of RSUD Dr. Soetomo Surabaya.

\section{Site of Foreign Bodies}

\section{RESULTS}

The most common site for foreign bodies was ear, followed by nose, then lastly throat. This data might be indicating that ear was the most common anatomical region on people to insert all kind of things since due to insertion of things on ear, it didn't really caused physiological problem, unlike insertion on nose that could lead to hard on breathing and insertion on throat that could lead to obstruction on airway and digestive system.

Table 1. Site of foreign bodies

\begin{tabular}{ccc}
\hline Site of foreign bodies & Frequency & Percentage \\
\hline Ear & 342 & 42.64 \\
Nose & 265 & 33.04 \\
Throat & 195 & 24.31 \\
\hline
\end{tabular}

\section{Age Group}

The most common age group was 0-10 years. This phenomena might happen due to explorative stage of children that led them to inserting things on their ear, nose, or throat. The second most common age group was above the 50, this might be happenned due to their old age and geriatric condition

Table 2. Age group of patients with foreign bodies

\begin{tabular}{ccc}
\hline Age group & Frequency & Percentage \\
\hline 0-10 years & 376 & 46.88 \\
11-20 years & 87 & 10.85 \\
21-30 years & 89 & 11.10 \\
31-40 years & 84 & 10.47 \\
41-50 years & 73 & 9.10 \\
>50 years & 93 & 11.60 \\
\hline
\end{tabular}

Sex

The most common sex of patients was male. This could happen due to male more explorative especially on pediatric patients. However, more deep research might be needed to answer why there were more male patients rather than female patients.

Table 3. Sex of patients with foreign bodies

\begin{tabular}{ccc}
\hline Sex & Frequency & Percentage \\
\hline Male & 445 & 55.49 \\
Female & 357 & 44.51 \\
\hline
\end{tabular}

\section{Foreign Bodies}

Cotton was found to be the most common foreign bodies on ear. This could occur due to unsafe practice of cleaning the earwax without medical practitioner's guidance. 
Table 4. Foreign bodies on ear

\begin{tabular}{|c|c|c|}
\hline Foreign bodies & Frequency & Percentage \\
\hline \multicolumn{3}{|l|}{ Organic } \\
\hline Cotton & 173 & 50.58 \\
\hline Insect & 112 & 32.75 \\
\hline Seed & 6 & 1.75 \\
\hline Nut & 5 & 1.46 \\
\hline Others & 9 & 2.63 \\
\hline \multicolumn{3}{|l|}{ Anorganic } \\
\hline Bead & 26 & 7.61 \\
\hline Metal & 7 & 2.05 \\
\hline Styrofoam & 2 & 0.58 \\
\hline Candle & 1 & 0.29 \\
\hline Sand & 1 & 0.29 \\
\hline
\end{tabular}

The most common foreign bodies on nose was bead. This happen especially on pediatric patients since they were on their explorative stage and bead was a common thing found around them. They end up inserting the bead to their organ that within their reach, which was their nose.

Table 5. Foreign bodies on nose

\begin{tabular}{|c|c|c|}
\hline Foreign bodies & Frequency & Percentage \\
\hline \multicolumn{3}{|l|}{ Organic } \\
\hline Nut & 36 & 13.58 \\
\hline Seed & 18 & 6.79 \\
\hline Rubber & 9 & 3.40 \\
\hline Candy & 6 & 2.26 \\
\hline Others & 20 & 7.55 \\
\hline \multicolumn{3}{|l|}{ Anorganic } \\
\hline Bead & 137 & 51.70 \\
\hline Metal & 10 & 3.80 \\
\hline Stponge & 9 & 3.40 \\
\hline Stone & 8 & 3.02 \\
\hline Others & 12 & 4.53 \\
\hline
\end{tabular}

The most common foreign bodies on throat was fishbone. This could occur because it was hard to differentiate fish bone with their meat, so it end up swallowed with the meat of fish.

Table 6. Foreign bodies on throat

\begin{tabular}{ccc}
\hline Foreign bodies & Frequency & Percentage \\
\hline Organic & & \\
Fish bone & 166 & 85.13 \\
Wood & 5 & 2.56 \\
Chicken bone & 4 & 2.05 \\
Meat & 2 & 1.03 \\
Others & 5 & 2.56 \\
Anorganic & & \\
Metal & 7 & 3.59 \\
Cable & 3 & 1.54 \\
Dentures & 2 & 1.03 \\
Bead & 1 & 0.51 \\
\hline
\end{tabular}

\section{Therapy}

The most common therapy for foreign bodies on ear was extraction with 332 procedure $(97.80 \%)$. Adding to that, some cases needed more than extraction like the need of analgetic in 2 procedures $(0.58 \%)$. There was one patient that needed to be admitted to the ward for further therapy. 
Table 7. Therapy for foreign bodies on ear

\begin{tabular}{ccc}
\hline Therapy & Frequency & Percentage \\
\hline Extraction & 332 & 97.80 \\
Extraction + analgetic & 2 & 0.58 \\
Extraction + analgetic + antibiotic & 2 & 0.58 \\
Extraction + analgetic + povidone iodine & 2 & 0.58 \\
Extraction + antibiotic & 1 & 0.29 \\
Extraction + burrowi ear pack & 1 & 0.29 \\
Extraction + povidone iodine & 1 & 0.29 \\
Admitted to ward & 1 & 0.29 \\
\hline
\end{tabular}

The most common therapy for foreign bodies on nose was extraction with 261 procedures (98.49\%). Adding to that, some cases needed more than extraction like the need of general anasthesia in 2 procedures $(0.75 \%)$.

Table 8. Therapy for foreign bodies on nose

\begin{tabular}{ccc}
\hline Therapy & Frequency & Percentage \\
\hline Extraction & 261 & 98.49 \\
Extraction + general anasthesia & 2 & 0.75 \\
Extraction + irigation & 1 & 0.38 \\
Extraction + nasal douche & 1 & 0.38 \\
\hline
\end{tabular}

The most common therapy for foreign bodies on ear was extraction with 186 procedures (95.38\%). There was one patient $(0.51 \%)$ that blood sugar needed to be regulated due to its diabetic condition. There were 4 patients that needed to be admitted to the ward for further therapy and observation.

Table 9. Therapy for foreign bodies on ear

\begin{tabular}{ccc}
\hline Therapy & Frequency & Percentage \\
\hline Extraction & 186 & 95.38 \\
Analgetic + antibiotic & 2 & 1.03 \\
Backblow & 1 & 0.51 \\
Extraction + analgetic + blood sugar regulation & 1 & 0.51 \\
Oral gargle + antibiotic + analgetic & 1 & 0.51 \\
Admitted to ward & 4 & 2.05 \\
\hline
\end{tabular}

\section{Complication}

Most of the patients with foreign bodies on their ear showed no complication after the extraction procedure with the number of 337 patients (98.54\%). However, there was one patient $(0.29 \%)$ with facial nerve paralysis due to metal, battery to be precise, on their ear. There were 4 patients $(1.17 \%)$ with ear cannal laceration.

Table 10. Complication of patients with foreign bodies on ear

\begin{tabular}{ccc}
\hline Complication & Frequency & Percentage \\
\hline Ear cannal laceration & 4 & 1.17 \\
Facial nerve paralysis & 1 & 0.29 \\
No complication & 337 & 98.54 \\
\hline
\end{tabular}

Most of the patients with foreign bodies on their nose showed no complication after the extraction procedure with the number of 265 patients (99.62\%). However, there was one patient $(0.38 \%)$ with failure on foreign bodies extraction.

Table 11. Complication of patients with foreign bodies on nose

\begin{tabular}{ccc}
\hline Complication & Frequency & Percentage \\
\hline Failure on extraction & 1 & 0.38 \\
No complication & 264 & 99.62 \\
\hline
\end{tabular}


Most of the patients with foreign bodies on their throat showed no complication after the extraction procedure with the number of 190 patients $(97.44 \%)$. However, there was one patient $(0.51 \%)$ with diffuse pulmonary haemorrage.

Table 12. Complication of patients with foreign bodies on throat

\begin{tabular}{ccc}
\hline Complication & Frequency & Percentage \\
\hline Hypopharingeal lession & 2 & 1.03 \\
Base of tongue lession & 1 & 0.51 \\
Diffuse pulmonary haemorrage & 1 & 0.51 \\
Epiglotitis & 1 & 0.51 \\
No complication & 190 & 97.44 \\
\hline
\end{tabular}

\section{DISCUSSION}

The studies shows that the most common site for foreign bodies was in the ear and nose became the second most common site fo foreign bodies ${ }^{(2-4)}$. Those studies allign with the finding of this study that found ear as the most common site for foreign bodies.

The most common age group on foreign bodies in ear, nose, and throat was age group of 0-10 years. This result allign with other studies that shown the most common patient of foreign bodies was children under the age of 10 years old ${ }^{(3),(4)}$. Pre-schooled children was the most vulnurable group for foreign bodies insertion so that education needed to the parents in order to pressing the case of foreign bodies ${ }^{(5)}$.

The most common sex of patients with foreign bodies in ear, nose, and throat is male. This result allign with other studies that found men more vulnerable with foreign bodies on their ear, nose, or throat than woman (1), (4)

The most common foreign bodies found on the ear was cotton with 173 cases $(50.58 \%)$. Other studies also found that cotton is the most common foreign bodies found on the ear ${ }^{(1),(2)}$. However, other study shows that cotton is the second most common foreign bodies on ear, that study conclude that the most common one is seed (6). This slight difference may be caused by difference in population habit and geographical differences.

The most common foreign bodies found on the nose is bead with 137 cases (51.70\%). The same result was found in other study, it conclude that bead is the most common foreign bodies on nose ${ }^{(2)}$. However, other study found that bead was the second most common foreign bodies on nose, the most common was plastic toys ${ }^{(1)}$.

The most common foreign bodies found on the throat was fish bone with 166 cases $(85.13 \%)$. Same result was found on other studies, concluding that fish bone was the most common foreign bodies on throat ${ }^{(1) \text {, (2). }}$

Standard therapy procedure for foreign bodies whether it is in the ear, nose, or throat was extraction. That is why extraction is the most common procedure found in this study. Extra treatment needed when the patient have certain condition like when the patient was diabetic, blood sugar regulation was necessary. Some of the patients needed extra treatment and observation are being transferred to the ward.

Most of the patient with foreign bodies on their ear found no complication after the therapy being done. One particular case was noteworthy because there is complication of facial nerve paralysis due to battery on his ear. Alkali leakage from the battery could destroy the surrounding tissue and with delay in management, it could cause the facial nerve paralysis ${ }^{(7)}$.

The same phenomena also found on patient with foreign bodies on nose. Almost all of them found no complication after the necessary procedure was done but one. One patient needed extra steps because there is a failure on extraction.

Patients with foreign bodies on their throat also mostly shown no complication. There are complication like laceration and inflamation on certain part of tissue because of the contact made by our body and the foreign bodies. The noteworthy case was one patient with diffuse pulmonary haemorrage. Study was found that foreign bodies was the second most common cause of diffuse pulmonary haemorrage ${ }^{(8)}$. Inflamation could cause the blood vessels on bronchus become dilated and caused bleeding when coughing. Then, infection from microorganism could cause that bleeding being local thrombosis or necrosis and lastly could cause the pulmonary haemorrage ${ }^{(9)}$.

\section{CONCLUSION}

For the age group, educating the parents with children is necessary to pushing the number of children foreign bodies patients. Education also needed for caretaker of elderly since the elderly was the second most common patient of foreign bodies.

Cotton bud being the most common foreign bodies found on ear probably because of unsafe technique practiced to cleaning the earwax. Education also needed for patients so that they do not do that unsafe practice to 
cleaning the earwax. Bead being the most common foreign bodies found on nose may be caused by children that trying to play with it and end up inserting it to their nose. Fishbone being the most common foreign bodies on throat may be caused by high consumption of fish and it is hard to differentiate bone from fish flesh so it end up ingested by the patients.

Low incidence of complication shows that the doctor of emergency room is fully prepared to manage the foreign bodies cases. However, certain patient with certain condition like diabetic patient or certain foreign bodies type like battery may need extra observation to make sure there is minimal complication happened after the procedure.

\section{REFERENCES}

1. Kristyono, I. Benda Asing Telinga Hidung Tenggorok. In Koentjono WA., Juaniati, SH., and Santoso BS. (Eds.) Emergency on Ortholaryngology Head and Neck Surgery: Latest Clinical Update. Surabaya: Fakultas Kedokteran Universitas Airlangga. 2017;123-133

2. Adedeji T, Sogebi O, Bande S. Clinical spectrum of ear, nose and throat foreign bodies in North Western Nigeria. African Health Sciences. 2016;16(1):292.3.

3. Endican S, Garap J, Dubey S. Ear, nose and throat foreign bodies in Melanesian children: An analysis of 1037 cases. International Journal of Pediatric Otorhinolaryngology. 2006;70(9):1539-1545.

4. Sosir M, Palandeng O, Tumbel R. Benda Asing Telinga Hidung Tenggorok di Bagian/SMF THT-KL BLU RSU Prof. DR. R. D. Kandou Manado Periode Januari 2008 - Desember 2011. Jurnal Biomedik (JBM). 2013;4(3).

5. Cheng W, Tam P. Foreign-body ingestion in children: Experience with 1,265 cases. Journal of Pediatric Surgery. 1999;34(10):1472-1476.

6. Ogunleye A, Sogebi R. Otic foreign bodies in children in Ibadan, Nigeria. Nigerian Journal of Surgical Research. 2006;7(3).

7. Premachandra D, McRae D. Severe tissue destruction in the ear caused by alkaline button batteries. Postgraduate Medical Journal. 1990;66(771):52-53.

8. Tom LW, Weisman RA, Handler SD. 1980. Hemoptysis in children. Ann Otol Rhinol Laryngol 89: 419-424.

9. Mandal A, Kaur Sahi P. Pulmonary Hemorrhage in Children. Pulmonary and Critical Care Medicine. 2016;2(1). 